\title{
Whaling: Good News for Sperms, Bad for Minke Richard Fitter
}

The 1979 annual meeting of the International Whaling Commission, held as usual in London, represents a watershed. For the first time for several years it held out some real hope that the great whale herds of the southern oceans may before long be allowed slowly to build up again. But at the same time it became clear that whale stocks near continental coasts will be decimated still further, before low stocks throughout the world finally bring whaling to a halt, perhaps in the later 1980s. As long ago as 1931, when pelagic whaling with factory ships was in its infancy, a writer in the fournal of the Society for the Preservation of the Fauna of the Empire (as Oryx was then called), remarked that 'all previous whaling industries have declined and died through overfishing'. The same applies of course to all subsequent whaling industries, despite the existence of the IWC. As the great Swedish statesman Oxenstjern once remarked, with what little wisdom is the world governed!

The two main gains for whale conservation at the London meeting include a ban on pelagic whaling (i.e. in ocean-going ships) in the southern oceans except for minke whales, and a whale sanctuary over 40 million square miles of the southern Indian Ocean, an imaginative proposal from the Seychelles Government, a new member of the Commission, that was accepted. The pelagic whaling ban actually affects only sperm whales, for all other whale stocks in the southern oceans have been destroyed by a combination of the whaling nations' cupidity and the pusillanimity of their scientific advisers. However, we have to be thankful for small mercies, even while prophesying with some confidence that within two or three years there will have to be a total ban, because the still apparently thriving stocks of minke whales will also be overfished.

On the debit side, the Commission refused either to institute a three-year moratorium on the taking of sperm whales anywhere, or to contemplate a moratorium on coastal whaling, while the United States, for purely political reasons, insisted that its Eskimos must be allowed to hunt a stock of bowhead whales that even the IWC scientists unanimously recommended should be totally protected. Such was the wheeling and dealing going on all the time that some unkind person calculated, as the US bargained with Japan behind the scenes, that every bowhead whale gained for its quota by the United States cost the lives of more than a hundred sperm whales elsewhere. In a Dutch auction of this kind the conservationists and their clients, the whales, lose all along the line.

For the British conservationists there was one silver lining to their cloud. They were able to listen, for the first time for many years, to the British minister who opened the conference taking a conservationist stance. It fell to the Minister of State at MAFF, Mr Alick Buchanan Smith, to announce that the UK Government now supported the concept of a moratorium on commercial whaling until the nations produced reliable data so that whaling could be resumed on a sustainable yield basis. He disappointed some people by announcing, not an immediate ban on the import of sperm whale oil into the $\mathrm{UK}$, but an effort to persuade the EEC as a whole to make such a ban. However, 
we have the Minister's personal assurance that this is not a delaying tactic, and that, if the EEC proves resistant, the UK Government will act alone. Only the most die-hard manufacturers now claim that sperm oil is essential to their operations; US industry manages without it, and efficient British firms should not suffer from such a ban.

With the UK and Australia moving decisively into the conservationist column, and two new members, Sweden and the Seychelles, doing the same, the political battles within the IWC have become more open. Other new members, such as South Korea (almost a carbon copy of Japan - perhaps somebody has been doing some cloning!), Peru, Chile and Spain took a more equivocal stance, but at the same time some old members, such as Iceland and Norway, began to abstain instead of supporting Japan's every move. Next year there may be other new members - India, Kenya, Mauritius and Switzerland are all rumoured to be considering joining. Soon the IWC will be almost a miniature United Nations, as more and more nations come to realise that the world's whales could be a valuable resource for all, of which they are being deprived by the intemperate greed of a handful of advanced nations. If the present ugly rush to destroy the world's last remaining whale stocks for short-term gains can be quickly stopped, it is possible to contemplate a prosperous and humane whaling industry in 15 or 20 years' time, from which all nations, including the landlocked ones can benefit. It may well not happen, but in that case, we shall know where to pin the blame.

\section{Quotas for $1979 / 80$}

The following catch limits were set for the 1979/80 Antarctic whaling season and for the 1980 season elsewhere:

Sperm whale:

580 in the southern hemisphere, 1350 in the N. Pacific, 273 in the $\mathrm{N}$. Atlantic, nil in the $\mathrm{N}$. Indian Ocean. A reduction of 7718 since last year.

Fin whale: 604 in the N. Atlantic, nil everywhere else. An increase of 134.

Sei whale:

Bryde's whale: 100 in the N. Atlantic, nil everywhere else. An increase of 16.

Minke whale: 264 in the southern hemisphere, 479 in the N. Pacific, nil everywhere else. An increase of 289.

810 in the southern hemisphere, 1361 in the N. Pacific, 2543 in the N. Atlantic, nil in the N. Indian Ocean. An increase of 2831 .

Bowhead whale: $\quad 26$ struck or 18 landed; a reduction of one struck.

Blue, right, humpback and gray whales remain totally protected from commercial whaling in all areas, and so does the bottlenose whale in the $N$. Atlantic.

\section{Houbara in the Canaries}

A population of about 70 houbara bustards (possibly up to 100) on Fuerteventura, in the Canaries, is the estimate of the 1979 ICBP expedition which received support from the FPS Oryx $100 \%$ Fund. The 35 birds actually sighted in the survey included two family parties, each with two young. Illegal shooting, disturbance at the nest site, including eggtaking by goatherds, and food shortage were identified as the main factors keeping numbers down; a possible future threat is loss of habitat due to tourist development. On I,anzarote, which offers less suitable houbara habitat, seven birds were seen, including two young. 